\title{
SIMULATION OF CRISIS MANAGEMENT PROCESSES AS A MEANS OF EDUCATION
}

\author{
Pavel HRDINA ${ }^{1}$, Lenka MALÉŘOVÁ²
}

Vision paper

Abstract:
The vision paper deals with the current project that solves the determination, description,
and simulation of crisis management processes, with the aim to create a tool enabling
first-rate preparation for the staffers of crisis staffs, safety councils, and integrated rescue
system (IRS). This tool will enable the preparation to be performed under conditions
maximally similar to those of real situations, including psychological and time factors. In
this respect, the paper describes individual tasks of educational process and their phases,
means of emergencies selection and the progress of the project phase being in progress at
present.
Education, Crisis management, Simulator, Extraordinary events, Emergency.

\section{Introduction}

In 2010 the Faculty of Safety Engineering VŠB TU Ostrava acquired a project no. VG20102015043 named „Simulation of crisis management processes in the system of lifelong education of integrated rescue system units and public administration bodies" solved in the framework of the Safety Research of Czech Interior Ministry (SIMPROKIM). The project time frame is 2010 to 2015 . The project deals with the determination, description, and simulation of crisis management processes with the aim to create a tool enabling high-quality preparation for the staffers of crisis staffs, safety councils, and integrated rescue system. This tool will enable the preparation to be performed under conditions approximating those of real emergencies and crisis states, including psychological and time factors. The target groups are the staffers of crisis management on all the stages of public administration and integrated rescue system units.

The SIMPROKIM project aims to the establishing of such a system that creates the needed methodical, program and data backgrounds providing suitable education in the field of crisis management to above mentioned target groups. The inception of this project was inspired by similar facilities in Poland, Slovakia or Germany.

At present, the technical background has been established on the premises of the Faculty of Safety Engineering, where the instruction will take place (see Fig. 1).

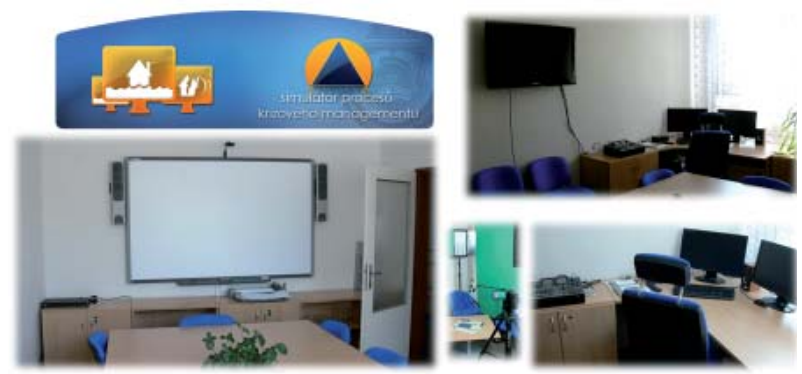

Fig. 1 SIMPROKIM, technical background

\section{Materials and methods}

One of the goals of the project will be a methodology of teaching. The education will be carried out in the form of the solving of a model safety situation on simulated area in the scope of three primal problems/tasks - Protection, Response, and Reconstruction.

The contents of primal problems are as follows:

\section{Protection}

This problem/task will comprise the complex of activities performed during preparations to emergencies. For the first approach and generalization, the following activities will be performed: to recognize the formation of emergency, to forestall the emergency by precautions, to reduce the consequences before the emergency (by

VŠB - Technical University of Ostrava, Faculty of Safety Engineering, Department of Civil Protection, Ostrava, Czech Republic, pavel.hrdina@vsb.cz

2 VŠB - Technical University of Ostrava, Faculty of Safety Engineering, Department of Civil Protection, Ostrava, Czech Republic, lenka.malerova@vsb.cz 
improved area resistance; by keeping the ability of action of human, material and other sources; by the preparation of reconstruction etc.) (ADAMEC, 2008).

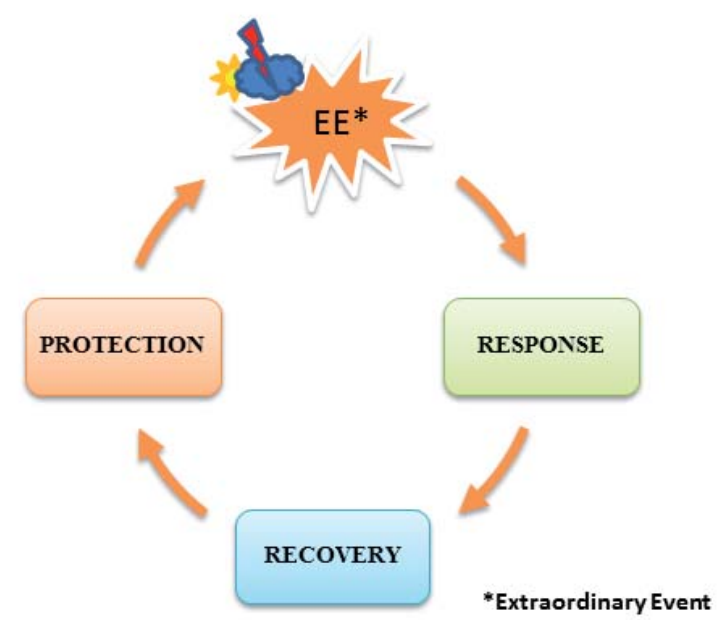

Fig. 2 Primal problems

\section{Response}

The aim of this task will be the familiarization with the consequences of an emergency in case the emergency is not prevented. This will be achieved partly by proactive measures mentioned in previous paragraph "Protection", partly by reactive measures related to rescue and settlement works. Thus the problem "Response" in general scale will comprise fighting the consequences of emergency and performing temporary repairs (warning, rescue works and care of affected, setting of the impact of an emergency (ADAMEC, 2008).

\section{Reconstruction}

The task originates from the need to define the activities in the frame of emergency management. It comprises the reconstitution of affected/damaged area into a stabilized state and related tasks, like the ensuring of basic functions in given area, i.e. properties serving for transport, for economic activities, for housing etc. The problem will also comprise not only how to stabilize the area but the creation of conditions for further development of damaged area as well (ADAMEC, 2008).

Individual tasks can be solved separately or complexly as interrelated whole, when all the tasks will be solved in corresponding phases. The difference among individual phases lies in the instructor's role extent. The tasks will be implemented in three phases:

\section{A. Teaching}

In general, the "Teaching" phase will have the form of controlled lecture. The instructor will gradually give participants the information about basic attributes needed for the assessment of "Protection", "Response", and "Reconstruction" problems. The instructor's involvement will reach up to $100 \%$.

\section{B. Training}

The „Training“" phase will comprise the testing of skills acquired by participants during the previous phase "Teaching" Practice of given problem and correct reaction to emerging situations in the scope of permanent working group field of activity will be part of training. The instructor's involvement should be around $50 \%$.

\section{Testing}

Testing of participants, who attended a course or one of partial problems, will be performed in this phase. The aim of this phase is to verify the adequateness of knowledge gained by participants. The instructor's role is minimal, $10 \%$ at most.

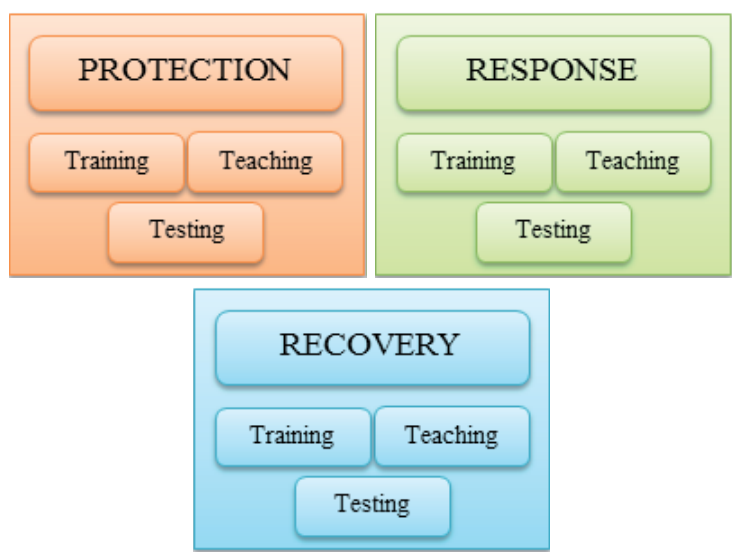

Fig. 3 Problems - individual phases

The educational process will be designed for individuals (her/his role in permanent working group) and for whole formed groups as well.

\section{Results}

Nowadays the project is in the phase of "Protection" task analysis. The stage being currently under way solves the algorithmization of processes used in the above mentioned primal problems and states the rules and communication bonds among all the subject participating in individual phases of teaching. The emphasis is put on the modular 
character of the system solving in order to enable repeated application of methods and materials prepared for individual tasks and easy integration of possible expansions. Apart from the core securing the education, the module that performs running and final assessment of practice is also part of the system.

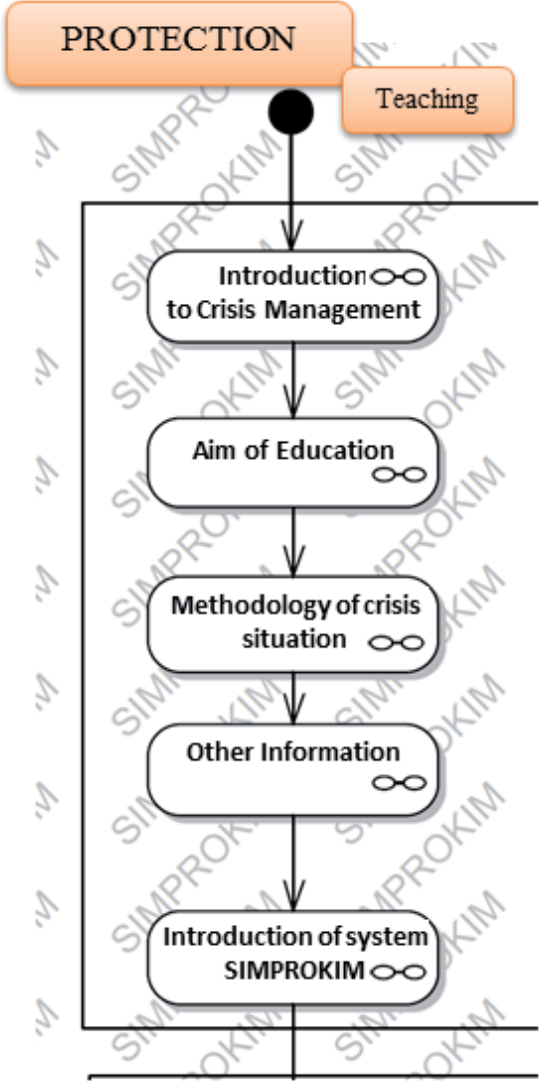

Fig. 4 Example of partial phase algorithm of the "Teaching" module

Suitable types of emergencies, which will be simulated in the area of interest, had to be chosen for the practices implementation. The emergency is defined as a harmful effect of forces and phenomena caused by human activities, by natural actions, and also accidents endangering life, health, property or environment, and requiring rescue and settlement works (Law No. 239/2000). The primal indicators of the relevancy of emergencies are the statistics providing the frequency of occurrence of given emergency.

Data from the database of statistical monitoring of events, administered by General Management of Fire Rescue Service, will be used for the comparison of the frequencies of emergency occurrence on the territory of Moravian-Silesian Region (MSR), which constitutes the target area.
Tab. 1 Distribution of all the extraordinary events in MSR according to the intervention type (MALÝ, 2011)

\begin{tabular}{|l|c|c|c|c|c|}
\hline \multicolumn{1}{|c|}{ Sort of Event } & $\mathbf{2 0 0 6}$ & $\mathbf{2 0 0 7}$ & $\mathbf{2 0 0 8}$ & $\mathbf{2 0 0 9}$ & $\mathbf{2 0 1 0}$ \\
\hline $\begin{array}{l}\text { Technical } \\
\text { Assistance }\end{array}$ & 10778 & 11478 & 8751 & 9363 & 13373 \\
\hline Fire & 2742 & 3098 & 2880 & 2618 & 2342 \\
\hline Traffic Accident & 1895 & 2124 & 2123 & 2014 & 1963 \\
\hline $\begin{array}{l}\text { Rescue of Persons } \\
\text { and Animals }\end{array}$ & 967 & 1126 & 1057 & 1019 & 1064 \\
\hline $\begin{array}{l}\text { Leak of Dangerous } \\
\text { Substance }\end{array}$ & 629 & 643 & 651 & 547 & 541 \\
\hline False Alarm & 589 & 589 & 865 & 849 & 842 \\
\hline Natural Disaster & 538 & 1575 & 1960 & 1208 & 153 \\
\hline Other & 29 & 29 & 35 & 24 & 52 \\
\hline $\begin{array}{l}\text { Other } \\
\text { Extraordinary } \\
\text { Event }\end{array}$ & 17 & 1 & 5 & 4 & 5 \\
\hline $\begin{array}{l}\text { Total Number of } \\
\text { Trips }\end{array}$ & 18184 & 2063 & 18327 & 17646 & 20335 \\
\hline
\end{tabular}

Tab. 2 Emergencies of natural character, MoravianSilesian Region (MALÍK, 2011)

\begin{tabular}{|c|c|c|c|c|c|c|c|}
\hline $\begin{array}{c}\text { Natural } \\
\text { Disaster }\end{array}$ & $\mathbf{2 0 0 6}$ & $\mathbf{2 0 0 7}$ & $\mathbf{2 0 0 8}$ & $\mathbf{2 0 0 9}$ & $\mathbf{2 0 1 0}$ & Average & Total \\
\hline $\begin{array}{c}\text { Flood, } \\
\text { Rain }\end{array}$ & 341 & 637 & 420 & 564 & 2393 & 871 & 4355 \\
\hline Storm & 88 & 732 & 1667 & 632 & 736 & 771 & 3855 \\
\hline Snow, Ice & 306 & 215 & 0 & 119 & 2071 & 542,2 & 2711 \\
\hline Landslide & 0 & 0 & 1 & 0 & 12 & 2,6 & 13 \\
\hline
\end{tabular}

As far as the teaching and practice are concerned, extraordinary events at which the declaration of crisis state is expected are considered relevant. Those events are labeled crisis situations. The crisis situation is such an emergency that cannot be contained by normal activities of IRS units and public administration bodies. To contain these emergencies, certain measures have to be accepted, or personal rights and freedoms have to be curtailed. So called Typified Plans have been prepared for containing these crisis situations that characterize the crisis situation and suggest possible measures for their containment and the sphere of involvement of various crisis management organs (SMETANA and ZDRÁHAL 2011; ŠENOVSKÝ, 2011).

For the pilot part of the project, flood can be considered suitable extraordinary event/crisis situation, in the first place on the basis of the probability of its occurrence, consequences, extent and the array of well mapped bygone occurrences. In future, the system will be expanded by other types of emergencies and/or their combination. The following events have been classified extraordinary: 
- traffic accident,

- forest fire - areal,

- leak of dangerous substance,

- fire of industrial object or waste dump.

As mentioned above, the task "Protection" is built as a complex of activities that guide the course participants to the assessment of actual situation in the place of emergency in accordance with available information. The crisis plan of the region, emergency plans, flood plan or mapped risks in the area of interest are considered the most useful available information. Based on these information, the participants subsequently assess the supposed impacts of selected emergency in the area on inhabitants, property or environment, and evaluate if the existing precautionary measures are adequate. During this task, the participants gain and practice basic knowledge in the field of crisis management, i.e. information about the function and action of public administration at times of emergency solving up to crisis state declaration, about the activities of safety council and regional crisis staff and municipalities with extended competence (MEC). The flows of information between regional crisis staff and MEC will be indicated. The course participants should also be able to determine or expose various types of discrepancies between presented documents and actual situation in the area of interest. The tasks "Response" and "Reconstruction" smoothly follow the task "Protection".

\section{References}

ADAMEC, Vilém (2008). Studie možností stanovení úrovně civilní nouzové připravenosti územních celků. Habilitační práce. Ostrava: Fakulta bezpečnostního inženýrství, VŠB - TUO, 2008 (in Czech).

GREEN, L. V., KOLESAR, P. J. (2004). Improving emergency responsiveness with management science. Management Science, New York. 2004, Vol. 50, No. 8, pp. 1001-1014. ISSN 00251909.

MALÍK, Ondřej (2011). Studie vzniku a následků mimořádných událostí - živelních pohrom. Diplomová práce. Ostrava : Fakulta bezpečnostního inženýrství, VŠB - TUO - Katedra ochrany obyvatelstva, 2011 (in Czech).

MALÝ, Radek (2011). Studie vzniku a následků mimořádných událostí - průmyslových havárií. Diplomová práce. Ostrava : Fakulta bezpečnostního inženýrství, VŠB - TUO - Katedra ochrany obyvatelstva, 2011 (in Czech).

MOSKOWITZ, H. DRNEVICH, P., ERSOY, O. ALTINKEMER, K., CHATURVEDI, A. (2011). Using Real-Time Decision Tools to Improve Distributed Decision-Making Capabilities in High-Magnitude Crisis Situations. Decisions Science, United States, 2011, Vol. 42, No. 2, pp. 477-493. ISSN 00117315.

SMETANA, Marek, ZDRÁHAL, Karel (2011). Vybrané problémy terminologie užívané v souvislosti s krizovým řízením v právním rámci ČR. Sborník vědeckých praci Vysoké školy báňské - Technické univerzity Ostrava, Řada bezpečnostního inženýrství. Ostrava, 2011, roč. 6, č. 1, s. 23-26. ISSN 1801-17694. (in Czech)

ŠENOVSKÝ, Pavel (2011). Hodnocení zranitelnosti obyvatelstva proti dlouhodobým účinkům povodní. Sborník vědeckých prací Vysoké školy báňské - Technické univerzity Ostrava, Řada bezpečnostního inženýrství. Ostrava, 2011, roč. 6, č. 1, s. 33-38. ISSN 1801-17694-38 (in Czech).

Zákon č. 239/2000 Sb., ze dne 9. srpna 2000 o integrovaném záchranném systému a o změně některých zákonů, ve znění pozdějších předpisů (in Czech). 